\title{
EFFECT OF THE POSITION OF AN EPOXY GROUP ON THE H-GRAPHENE CLUSTER PROPERTIES: THE DENSITY FUNCTIONAL THEORY CALCULATIONS
}

\author{
Fahimeh Shojaie \\ Semiconductors group, Institute of Science and High Technology and Environmental Sciences, \\ Graduate University of Advanced Technology, Kerman, Iran \\ e-mail:f.shojaie@kgut.ac.ir
}

(Received October 27, 2018; in final form - December 17, 2018)

\begin{abstract}
Chemical functionalization of $\mathrm{H}$-graphene cluster by an epoxy group has been deemed to be an effective way to tune the electronic structure of H-graphene and open its band gap. It is important to understand the atomic structure of H-graphene oxide in order to utilize its fundamental properties and explore its potential applications. Therefore, it is essential to know the arrangement of oxygen-containing functional groups in H-graphene oxide. A computational study using DFTbased reactivity descriptors to identify favorable sites of epoxy groups on the H-graphene surface was performed in this work. Structural, electronic and optical properties of epoxy groups in various positions of the $\mathrm{H}$-graphene surface were compared. All calculations were performed using $\mathrm{DMol}^{3}$ code in Materials Studio. Optical properties of epoxy groups show that the electron transmissions from HOMO to LUMO, which are related to the energy gap, have the highest wavelength and the least amount of oscillator power in all structures. The highest wavelength, which occurs in the transmission $\mathrm{H} \rightarrow \mathrm{L}(1512 \mathrm{~nm})$, is related to structure 10. This is consistent with the results of the energy gap and global softness. The energy of interactions is negative in all structures, which indicates that the interaction between the oxygen atom and H-graphene, which results in the formation of H-graphene epoxy, is exothermic. The number of electron occupancy states in the energy levels between HOMO and LUMO has changed for oxygen-absorbed H-graphene, which indicates the effect of oxygen on the H-graphene surface.
\end{abstract}

Key words: H-graphene cluster, epoxy group, density functional theory, structural, electronic and optical properties.

DOI: https://doi.org/10.30970/jps.23.1301

PACS number(s): 31.15.A-

\section{INTRODUCTION}

The graphene is a two-dimensional sheet of $s p^{2}$ carbon atoms and is used in many fields of science and technology due to its exceptional and unusual properties [1, $2]$. The presence of functional groups changes the properties and applications of graphene. Graphene oxide is one of the most significant structures of graphene, which exhibits high electrical conductivity due to its free electrons. Graphene oxide plays an important role in applications such as gas sensors, electronic devices and optical devices. Graphene oxide consists of four types of functional groups: epoxy $(-\mathrm{O}-)$, hydroxyl $(-\mathrm{OH})$, carbonyl $(-\mathrm{C}=\mathrm{O})$ and carboxyl $(-\mathrm{COOH})[3-9]$. Functionalized graphene is suitable to be used in composite structures and graphene epoxy nanocomposites have been studied extensively $[10,11]$. Polymer composites, reinforced with functionalized graphene nanoparticles, have many applications $[12,13]$.

Recently, theoretical studies have been conducted on the adsorption of gases and molecules by $\mathrm{H}$-graphene oxide (H-GO): for example, the design of models to understand the reaction mechanism of between ammonia and H-GO [14], the study of the interactions of three amino acids (glycine, histidine and phenylalanine) with perfect, defected $\mathrm{H}$-graphene as well as $\mathrm{H}-\mathrm{GO}$ [15].
Basak et al. have studied optical and electronic properties of diamond-shaped H-graphene quantum dots by arge-scale all-electron correlated calculations [16]. They concluded that changes in the linear absorption spectrum were observed with increasing the size of diamondshaped H-graphene quantum dots. The structural stability and electronic properties of $\mathrm{H}$-graphene clusters in two shapes, rectangular and circular (consisting of 6 to 160 carbon atoms and hydrogen termination at the boundary edges), have been investigated by Karki et al. [17]. They have studied the adsorption of oxygen atoms on flat $\mathrm{H}$-graphene clusters $\left(\mathrm{C}_{24} \mathrm{H}_{12}, \mathrm{C}_{30} \mathrm{H}_{14}, \mathrm{C}_{48} \mathrm{H}_{18}\right.$ and $\mathrm{C}_{70} \mathrm{H}_{22}$ ), their calculations have been performed based on DFT using Gaussian, B3LYP method and basis set $3-21 \mathrm{G}$.

In these and other studies, researchers have studied $\mathrm{H}$-graphene epoxy using several functional groups located randomly in the H-graphene epoxy structure. In this work, active sites of an oxygen-based functional group in $\mathrm{H}$-graphene epoxy structures were determined, and the reason for the selection of this functional group is the important role that oxygen plays in the structure of $\mathrm{H}$ graphene oxide and also its application in all theoretical and empirical studies. In this research work, the optical and structural properties of H-graphene epoxy have been investigated in order to detect its reactive locations 
and also compare their properties. Reactive locations of H-graphene epoxy have not been reported. Such studies may help us to understand electronic structures better and may also help us to design new H-graphene structures based on functional groups. Adsorption of gases and drugs on materials can be computed more accurately if the electronic structure of the adsorbing material is well determined.

\section{COMPUTATIONAL METHODS}

All calculations were performed using $\mathrm{DMol}^{3}$ code in Materials Studio 5.5. $\mathrm{DMol}^{3}$ code calculations are based on the density functional theory and are used to solve the Kohn-Sham equations [18-20]. The generalized gradient approximation (GGA) according to Perdew and Wang (PW91) and the double numerical plus polarization function (DNP) were used in all calculations [21]. All electrons were considered for calculations involving nuclear states [22]. The total energy convergence criteria for self-consistent field (SCF) were set to $106 \mathrm{eV}$. All structures have a positive frequency after optimization, indicating that they have at least same energy as the potential energy level.

The energy of the absorption between oxygen and $\mathrm{H}$ graphene in H-graphene epoxy is calculated from Eq. (1).

$$
E_{\mathrm{ads}}=E_{\mathrm{H} \text {-graphene epoxy }}-\left(E_{\mathrm{H} \text {-graphene }}+E_{\text {Oxygen }}\right) .
$$

In Eq. (1), $E_{\text {ads }}$ is the energy of the interaction between oxygen and graphene, $E_{\mathrm{H} \text {-graphene epoxy }}$ is the total energy of $\mathrm{H}-\mathrm{H}$-graphene epoxy, $E_{\mathrm{H} \text {-graphene }}$ is the total $\mathrm{H}$ graphene energy, and $E_{\text {Oxygen }}$ is the total oxygen energy.

Fukui functions have been used to determine the best location of oxygen on $\mathrm{H}-\mathrm{H}$-graphene.

$$
\begin{aligned}
& f^{+}(k)=p_{(N+1)}-p_{(N)}(k), \\
& f^{-}(k)=p_{(N)}-p_{(N-1)}(k) .
\end{aligned}
$$

The Fukui functions for nucleophilic and electrophilic attacks are defined by Eq. (2) and Eq. (3) respectively [22], where $p_{(N+1)}(k), p_{(N-1)}(k)$ and $p_{(N)}(k)$ are the electronic populations on atom $k$ for $N+1, N-1$ and $N$ electron systems, respectively. Eq. (2) and Eq. (3) can also be expressed in terms of the global softness $(S)$, which is the inverse of hardness. The different local softnesses used to describe the reactivity of the $k$ th atom in a molecule can be written as Eq. (4) and Eq. (5) [23],

$$
\begin{aligned}
S^{-}(k) & \simeq S f^{-}(k), \\
S^{+}(k) & \simeq S f^{+}(k), \\
f^{2}(k) & =\left[f^{+}(k)-f^{-}(k)\right],
\end{aligned}
$$

where $S^{+}$and $S^{-}$represent the local softness quantities describing nucleophilic and electrophilic attacs respectively. Eq. (6) was proposed for describing reactive sites in 2005 [24]. If $f^{2}(k)>0$, then the sites favored a nucleophilic attack, whereas sites are susceptible to an electrophilic attack if $f^{2}(k)<0$.

Quantum chemistry descriptors provide information on the chemical reactivity of molecules. One of these descriptors is global softness. If the global softness of a molecule is high, then the molecule will be less stable and more reactive. The global softness is derived from Eq. (7).

$$
\sigma=\frac{2}{E_{\mathrm{LOMO}}-E_{\mathrm{HOMO}}}
$$

\section{DISCUSSION AND CONCLUSION}

A simulation study was carried out on H-graphene. The H-graphene consisted of 48 carbon atoms and 18 hydrogen atoms $\left(\mathrm{C}_{48} \mathrm{H}_{18}\right)$. The $\mathrm{H}$-graphene boundary carbon atoms are limited by hydrogen atoms (Fig. 1, part A) and the epoxy functional group was placed in various positions between carbon atoms on the surface of the $\mathrm{H}$ graphene. The sheet of the H-graphene with the number of positions that the epoxy group was placed between the two carbon atoms is shown in Fig. 1, part B. Fig. 1 part $\mathrm{C}$ shows the state of the epoxy group in position 3 (between carbon numbers 4 and 10).

In this work, 20 locations of the epoxy group were investigated. The following calculations have been performed for the 20 optimized H-graphene epoxy structures.
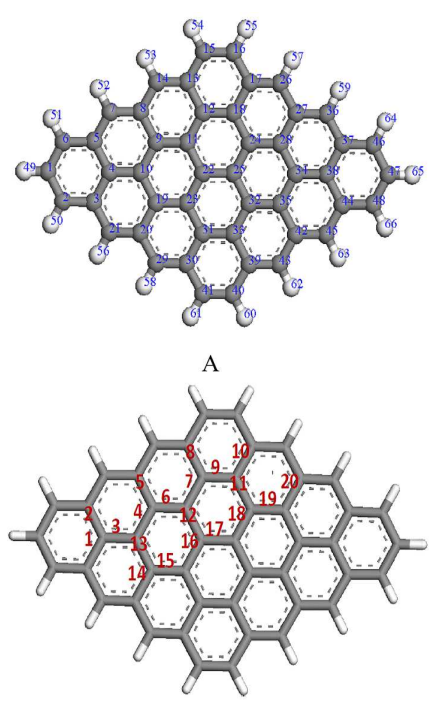

B

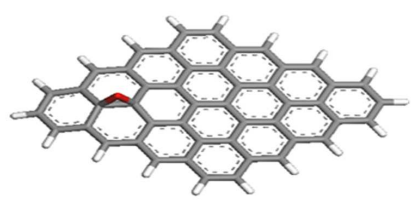

$\mathrm{C}$

Fig. 1. Optimized Structure of H-graphene: H-graphene A with Atomic Number Display, H-graphene B showing locations of oxygen between two carbon atoms and H-graphene $\mathrm{C}$ showing structure 3 of H-graphene epoxy. 


\section{BOND LENGTH AND BOND ORDER}

Table 1 shows the bond length and bond order of Hgraphene and H-graphene epoxy structures which were calculated by Mayer and Mulliken methods [25]. The results show that the oxygen bonding increases the bond lengths of carbon atoms. Oxygen bonding causes the carbon-carbon bond length to increase in all $\mathrm{H}$-graphene epoxy structures. An increase in bond length results in a decrease in bond order, which indicates that the carbon- carbon bonds in H-graphene epoxy structures are weaker than the corresponding bonds in H-graphene.

The differences between the $\mathrm{C}-\mathrm{O}$ bond lengths in each $\mathrm{H}$-graphene epoxy structure are insignificant. The carbon-carbon bond lengths at the edges of H-graphene and H-graphene epoxy are slightly longer than their corresponding bond lengths on their surfaces, suggesting that the edge bonds are weaker. Structures 1, 2, 5, 8, 10,14 , and 20 relate to the placement of oxygen between two carbon atoms on H-graphene edges.

\begin{tabular}{|c|c|c|c|c|c|c|c|}
\hline \multirow[t]{2}{*}{ Model } & \multirow[t]{2}{*}{ Bond } & \multirow[t]{2}{*}{ BL(H-G) } & \multirow[t]{2}{*}{ BL(H-GO) } & \multicolumn{2}{|c|}{ BO (H-G) } & \multicolumn{2}{|c|}{ BO(H-GO) } \\
\hline & & & & Ma & Mu & Ma & Mu \\
\hline & $\mathrm{C} 3-\mathrm{C} 4$ & 1.432 & 1.600 & 1.193 & 0.932 & 0.733 & 0.437 \\
\hline \multirow[t]{3}{*}{1} & $\mathrm{O}-\mathrm{C} 3$ & - & 1.450 & - & - & 0.850 & 0.335 \\
\hline & $\mathrm{O}-\mathrm{C} 4$ & - & 1.430 & - & - & 0.901 & 0.364 \\
\hline & $\mathrm{C} 4-\mathrm{C} 5$ & 1.432 & 1.478 & 1.193 & 0.932 & 1.022 & 0.804 \\
\hline \multirow[t]{3}{*}{2} & $\mathrm{O}-\mathrm{C} 4$ & - & 1.446 & - & - & 1.000 & 1.000 \\
\hline & $\mathrm{O}-\mathrm{C} 5$ & - & 2.460 & - & - & 0.888 & 0.340 \\
\hline & $\mathrm{C} 4-\mathrm{C} 10$ & 1.416 & 1.536 & 1.250 & 0.977 & 0.816 & 0.496 \\
\hline \multirow[t]{3}{*}{3} & $\mathrm{O}-\mathrm{C} 4$ & - & 1.446 & - & - & 0.888 & 0.344 \\
\hline & $\mathrm{O}-\mathrm{C} 10$ & - & 1.454 & - & - & 0.870 & 0.34 \\
\hline & $\mathrm{C} 9-\mathrm{C} 10$ & 1.423 & 1.532 & 1.220 & 0.956 & 0.821 & 0.505 \\
\hline \multirow[t]{3}{*}{4} & $\mathrm{O}-\mathrm{C} 9$ & - & 1.448 & - & - & 0.884 & 0.342 \\
\hline & $\mathrm{O}-\mathrm{C} 10$ & - & 1.461 & - & - & 0.859 & 0.329 \\
\hline & $\mathrm{C} 8-\mathrm{C} 9$ & 1.438 & 1.532 & 1.162 & 0.908 & 0.745 & 0.447 \\
\hline \multirow[t]{3}{*}{5} & $\mathrm{O}-\mathrm{C} 8$ & - & 1.453 & - & - & 0.838 & 0.32 \\
\hline & $\mathrm{O}-\mathrm{C} 9$ & - & 1.458 & - & - & 0.893 & 0.354 \\
\hline & $\mathrm{C} 9-\mathrm{C} 11$ & 1.412 & 1.516 & 1.265 & 0.985 & 0.84 & 0.517 \\
\hline \multirow[t]{3}{*}{6} & $\mathrm{O}-\mathrm{C} 9$ & - & 1.454 & - & - & 0.88 & 0.331 \\
\hline & $\mathrm{O}-\mathrm{C} 11$ & - & 1.461 & - & - & 0.867 & 0.328 \\
\hline & $\mathrm{C} 11-\mathrm{C} 12$ & 1.426 & 1.532 & 1.206 & 0.948 & 0.805 & 0.489 \\
\hline \multirow[t]{3}{*}{7} & $\mathrm{O}-\mathrm{C} 11$ & - & 1.458 & - & - & 0.872 & 0.343 \\
\hline & $\mathrm{O}-\mathrm{C} 12$ & - & 1.453 & - & - & 0.878 & 0.349 \\
\hline & $\mathrm{C} 12-\mathrm{C} 13$ & 1.440 & 2.190 & 1.150 & 0.901 & 1.00 & 1.00 \\
\hline \multirow[t]{3}{*}{8} & $\mathrm{O}-\mathrm{C} 12$ & - & 1.375 & - & - & 0.995 & 0.618 \\
\hline & $\mathrm{O}-\mathrm{C} 13$ & - & 1.401 & - & - & 0.928 & 0.538 \\
\hline & $\mathrm{C} 12-\mathrm{C} 18$ & 1.405 & 1.446 & 1.298 & 1.003 & 0.860 & 0.534 \\
\hline 9 & $\mathrm{O}-\mathrm{C} 12$ & - & 1.567 & - & - & 0.871 & 0.318 \\
\hline & $\mathrm{O}-\mathrm{C} 18$ & - & 1.568 & - & - & 0.871 & 0.318 \\
\hline & $\mathrm{C} 17-\mathrm{C} 18$ & 1.440 & 1.602 & 1.150 & 0.901 & 0.723 & 0.433 \\
\hline 10 & $\mathrm{O}-\mathrm{C} 17$ & - & 1.450 & - & - & 0.852 & 0.329 \\
\hline & $\mathrm{O}-\mathrm{C} 18$ & - & 1.435 & - & - & 0.89 & 0.358 \\
\hline & $\mathrm{C} 18-\mathrm{C} 24$ & 1.426 & 1.531 & 1.206 & 0.948 & 0.82 & 0.507 \\
\hline 11 & $\mathrm{O}-\mathrm{C} 18$ & - & 1.453 & - & - & 0.877 & 0.333 \\
\hline & $\mathrm{O}-\mathrm{C} 24$ & - & 1.459 & - & - & 0.863 & 0.332 \\
\hline & $\mathrm{C} 11-\mathrm{C} 22$ & 1.425 & 1.543 & 1.209 & 0.947 & 0.805 & 0.489 \\
\hline 12 & $\mathrm{O}-\mathrm{C} 11$ & - & 1.452 & - & - & 0.872 & 0.343 \\
\hline & $\mathrm{O}-\mathrm{C} 22$ & - & 1.449 & - & - & 0.878 & 0.349 \\
\hline & C10-C19 & 1.423 & 1.532 & 1.220 & 0.956 & 0.821 & 0.505 \\
\hline 13 & $\mathrm{O}-\mathrm{C} 10$ & - & 1.461 & - & - & 0.859 & 0.329 \\
\hline & O-C19 & - & 1.449 & - & - & 0.884 & 0.342 \\
\hline & $\mathrm{C} 19-\mathrm{C} 20$ & 1.438 & 2.168 & 1.162 & 0.908 & 1.000 & 1.000 \\
\hline 14 & O-C19 & - & 1.373 & - & - & 0.998 & 0.613 \\
\hline & $\mathrm{O}-\mathrm{C} 20$ & - & 1.402 & - & - & 0.926 & 0.537 \\
\hline & $\mathrm{C} 19-\mathrm{C} 23$ & 1.412 & 1.517 & 1.265 & 0.985 & 0.840 & 0.517 \\
\hline 15 & O-C19 & - & 1.454 & - & - & 0.880 & 0.330 \\
\hline & $\mathrm{O}-\mathrm{C} 23$ & - & 1.461 & - & - & 0.867 & 0.328 \\
\hline & $\mathrm{C} 22-\mathrm{C} 23$ & 1.425 & 1.534 & 1.209 & 0.947 & 0.815 & 0.499 \\
\hline 16 & $\mathrm{O}-\mathrm{C} 22$ & - & 1.452 & - & - & 0.874 & 0.341 \\
\hline & $\mathrm{O}-\mathrm{C} 23$ & - & 1.456 & - & - & 0.867 & 0.334 \\
\hline & $\mathrm{C} 22-\mathrm{C} 25$ & 1.413 & 1.517 & 1.254 & 0.976 & 0.836 & 0.511 \\
\hline 17 & $\mathrm{O}-\mathrm{C} 22$ & - & 1.457 & - & - & 0.874 & 0.333 \\
\hline & $\mathrm{O}-\mathrm{C} 25$ & - & 1.457 & - & - & 0.874 & 0.333 \\
\hline & $\mathrm{C} 24-\mathrm{C} 25$ & 1.425 & 1.537 & 1.209 & 0.947 & 0.812 & 0.497 \\
\hline 18 & $\mathrm{O}-\mathrm{C} 24$ & - & 1.455 & - & - & 0.868 & 0.336 \\
\hline & $\mathrm{O}-\mathrm{C} 25$ & - & 1.451 & - & - & 0.876 & 0.342 \\
\hline & $\mathrm{C} 24-\mathrm{C} 28$ & 1.412 & 1.416 & 1.265 & 0.985 & 0.841 & 0.517 \\
\hline 19 & $\mathrm{O}-\mathrm{C} 24$ & - & 1.461 & - & - & 0.867 & 0.328 \\
\hline & $\mathrm{O}-\mathrm{C} 28$ & - & 1.454 & - & - & 0.88 & 0.331 \\
\hline & $\mathrm{C} 27-\mathrm{C} 28$ & 1.438 & 1.586 & 1.162 & 0.908 & 0.742 & 0.446 \\
\hline 20 & $\mathrm{O}-\mathrm{C} 27$ & - & 1.458 & - & - & 0.839 & 0.320 \\
\hline & $\mathrm{O}-\mathrm{C} 28$ & - & 1.436 & - & - & 0.893 & 0.355 \\
\hline
\end{tabular}

Table 1. The bond length and bond order of H-graphene and H-graphene epoxy structures.

Acronyms are: Mayer (Ma), Mulliken (Mu), H-graphene (G), H-graphene epoxy (GO), Bond Order (BO) and Bond length (BL). 


\section{MOLECULAR ORBITAL}

The energy gap is an important parameter for molecular reactivity. The stability and chemical reactivity of a system is determined by the difference between HOMO and LUMO, or the energy gap. Therefore, the smaller the energy gap, the more responsive the system will be. Energy gaps of H-graphene epoxy structures show that some structures have more energy than H-graphene and some structures have less energy than H-graphene (Fig. 2). For the cluster $\mathrm{C}_{48} \mathrm{H}_{18}$, the calculated value of the energy gap is $0.023 \mathrm{Ha}(0.636 \mathrm{eV})$, while the reported value in Ref. [17] is approximately $0.041 \mathrm{Ha}(1.1 \mathrm{eV})$. This difference may be due to the type of software and computational method.

Structures 10 and 9 have the lowest and highest energy gaps respectively. Therefore, the reactivity of structure 10 is even greater than H-graphene. Structure 9 has a low global softness, a higher energy gap and thus less reactivity. The global softness of $\mathrm{H}$-graphene is $3.143 \mathrm{eV}^{-1}$.

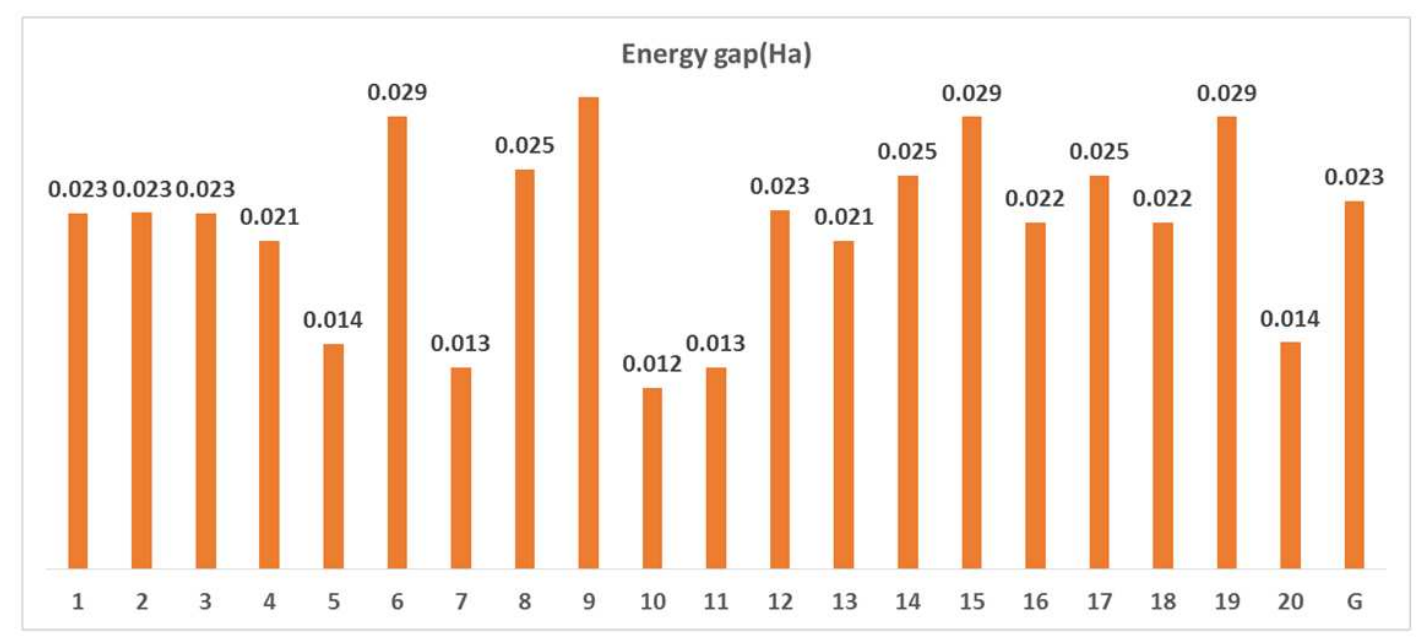

Fig. 2. Energy gap of H-graphene and H-graphene epoxy

\section{DENSITY OF STATES AND MAGNETIC PROPERTIES}

Figure S1 (hereafter, figure numbers S\# refer to the online supplementary material) shows the density of states in H-graphene and H-graphene epoxy and the number of available electron states. The densities of states of the structures with almost identical energy gaps are similar. For example, the difference between the density of states of structure 10 (the most reactive structure) and structure 9 is observable.Therefore, the energy gap matches the density of states. The calculations show that the H-graphene's Fermi surface is located on the energy of LUMO ( -0.141 Hartree), but the Fermi energies of the $20 \mathrm{H}$-graphene epoxy structures are located between the LUMO and HOMO energies. Oxygen bonding to two carbon atoms on the surface of H-graphene changes the H-graphene Fermi energy, which is calculated to be in the range of $-0.1420 \div-0.1436$ Hartree. Therefore, the number of electron occupation states in the Fermi level range between HOMO and LUMO changes after the absorption of oxygen on the surface of H-graphene. This is the effect of oxygen on the H-graphene surface.

One of the methods for determining the structures of ferromagnets is comparing their densities in a high and a low spin electron states. The difference between a high and a low spin electron states is related to magnetic momentum. Therefore, if the densities of a high and a low spin electron states of a system are symmetric, then the system is antiferromagnetic.

The analysis of the high and low spin state graphs shows that H-graphene is antiferromagnetic and the presence of oxygen between two carbon atoms in all positions on the surface of H-graphene has no effect on the magnetic properties of H-graphene (Fig. S2).

\section{FUKUI FUNCTIONS}

Fukui functions are used for calculating Fukui indices for electron centers (atoms sensitive to electrophiles) and electron-deficient centers (atoms sensitive to nucleophiles). The purpose of calculating the Fukui indices for $20 \mathrm{H}$-graphene epoxy structures was to compare their nucleophilic and electrophilic attractions and determine which H-graphene epoxy structures are most reactive. Figure S1 shows that shape HOMO with shape LUMO are almost the same in each of the graphene epoxy structures. Also, the negative and positive Fukui indices in each of the graphene epoxy structures are not very different (see Table 2). So, the results of the Fukui indices values are consistent with the results of the structures of HOMO and LUMO. Table 2 shows the Fukui indices and global softness of the H-graphene epoxy structures which were calculated by Mulliken and Hirschfeld methods.

The results show that oxygen in structure 10 of $\mathrm{H}$ - 
graphene epoxy has the highest value of $f^{-}, f^{+}, S^{-}$, $S^{+}$, and $f^{2}$. These values are consistent with the results obtained by the border orbitals method. Then there are more nucleophiles and electrophiles in the oxygen at location 10 of H-graphene epoxy than in the rest of the oxygen in other H-graphene epoxy structures. Eq. (5) shows that the oxygen in structures number 1, 2 and
5 is more electrophilic than the rest of the oxygen in $\mathrm{H}-$ graphene epoxy structures. Charge densities on all atoms of H-graphene epoxy structures, calculated by Mulliken method, show that the highest negative charge density occurs on the oxygen atom ( -0.387 to -0.460 electrons). Oxygen bonding to carbon atoms increases charge densities of H-graphene epoxy.

\begin{tabular}{|c|c|c|c|c|c|}
\hline \multirow[t]{2}{*}{ Model } & \multicolumn{2}{|c|}{$f^{-}$} & \multicolumn{2}{|c|}{$f^{+}$} & \multirow{2}{*}{$\frac{S^{-}}{\text {Mulliken }}$} \\
\hline & Mulliken & Hirshfeld & Mulliken & Hirshfeld & \\
\hline 1 & 0.021 & 0.018 & 0.019 & 0.016 & 0.068 \\
\hline 2 & 0.018 & 0.015 & 0.015 & 0.012 & 0.058 \\
\hline 3 & 0.016 & 0.013 & 0.016 & 0.013 & 0.052 \\
\hline 4 & 0.020 & 0.018 & 0.020 & 0.020 & 0.071 \\
\hline 5 & 0.023 & 0.021 & 0.021 & 0.019 & 0.118 \\
\hline 6 & 0.019 & 0.016 & 0.019 & 0.016 & 0.049 \\
\hline 7 & 0.019 & 0.017 & 0.023 & 0.022 & 0.037 \\
\hline 8 & 0.010 & 0.010 & 0.012 & 0.010 & 0.029 \\
\hline 9 & 0.020 & 0.017 & 0.019 & 0.017 & 0.043 \\
\hline 10 & 0.023 & 0.021 & 0.023 & 0.022 & 0.147 \\
\hline 11 & 0.021 & 0.020 & 0.021 & 0.020 & 0.121 \\
\hline 12 & 0.018 & 0.016 & 0.018 & 0.016 & 0.058 \\
\hline 13 & 0.020 & 0.018 & 0.020 & 0.018 & 0.071 \\
\hline 14 & 0.012 & 0.011 & 0.012 & 0.010 & 0.035 \\
\hline 15 & 0.019 & 0.016 & 0.019 & 0.016 & 0.049 \\
\hline 16 & 0.019 & 0.017 & 0.019 & 0.017 & 0.063 \\
\hline 17 & 0.015 & 0.012 & 0.015 & 0.012 & 0.049 \\
\hline 18 & 0.018 & 0.016 & 0.020 & 0.018 & 0.060 \\
\hline 19 & 0.019 & 0.016 & 0.019 & 0.016 & 0.049 \\
\hline 20 & 0.022 & 0.019 & 0.022 & 0.021 & 0.112 \\
\hline \multirow[t]{2}{*}{ Model } & \multicolumn{2}{|c|}{$S^{+}$} & \multicolumn{2}{|c|}{$f^{2}$} & $S^{-}$ \\
\hline & Mulliken & Hirshfeld & Mulliken & Hirshfeld & Hirshfeld \\
\hline 1 & 0.062 & 0.052 & -0.002 & -0.002 & 0.058 \\
\hline 2 & 0.049 & 0.039 & -0.003 & -0.003 & 0.049 \\
\hline 3 & 0.052 & 0.042 & 0.000 & 0.000 & 0.042 \\
\hline 4 & 0.071 & 0.071 & 0.000 & 0.002 & 0.064 \\
\hline 5 & 0.108 & 0.098 & -0.002 & -0.002 & 0.108 \\
\hline 6 & 0.049 & 0.041 & 0.000 & 0.000 & 0.041 \\
\hline 7 & 0.045 & 0.043 & 0.004 & 0.005 & 0.033 \\
\hline 8 & 0.035 & 0.029 & 0.002 & 0.000 & 0.029 \\
\hline 9 & 0.041 & 0.037 & -0.001 & 0.000 & 0.037 \\
\hline 10 & 0.147 & 0.140 & 0.000 & 0.001 & 0.134 \\
\hline 11 & 0.121 & 0.115 & 0.000 & 0.000 & 0.115 \\
\hline 12 & 0.058 & 0.052 & 0.000 & 0.000 & 0.052 \\
\hline 13 & 0.071 & 0.063 & 0.000 & 0.000 & 0.063 \\
\hline 14 & 0.035 & 0.029 & 0.000 & -0.001 & 0.032 \\
\hline 15 & 0.049 & 0.041 & 0.000 & 0.000 & 0.041 \\
\hline 16 & 0.063 & 0.057 & 0.000 & 0.000 & 0.057 \\
\hline 17 & 0.049 & 0.039 & 0.000 & 0.000 & 0.039 \\
\hline 18 & 0.067 & 0.060 & 0.002 & 0.002 & 0.053 \\
\hline 19 & 0.049 & 0.041 & 0.000 & 0.000 & 0.041 \\
\hline 20 & 0.112 & 0.107 & 0.000 & 0.002 & 0.097 \\
\hline
\end{tabular}

Table 2. $f^{-}, f^{+}, S^{-}, S^{+}$and $f^{2}$ for oxygen atom in H-graphene epoxy structures.

\section{ELECTROSTATIC POTENTIAL}

Figure S3 shows the electrostatic potential energy in relation to the bond length (related to oxygen and carbon atoms attached to it) in H-graphene epoxy structures. As you can see, these shapes are consistent with the bond lengths in Table 1. For example, as Table 1 shows, in structure 2 , the values of the lengths of carbon-oxygen bonds are different (O-C4: 1.446 and $\mathrm{O}-\mathrm{C} 5: 2.460 \AA$ ). These results are consistent with the electrostatic po- tential energy in relation to the bond length (figure S3). Figure S3 shows that the distribution of electrostatic potential in H-graphene epoxy structures 1, 2, 5, 8, 10, 14 and 20 is not uniform. The distribution of electrostatic potential relates to the oxygen position between two carbon atoms on H-graphene edges. This non-uniform distribution of electrostatic potential is greater in structures 2,8 and 14 , which is consistent with the results of the bond length. 


\section{FAHIMEH SHOJAIE}

\section{INTERACTION ENERGY}

The energy of the interaction between oxygen and $\mathrm{H}$ graphene for the formation of H-graphene epoxy is summarized in Fig. 3. Figure 3 shows that the interaction energy is negative in all structures, which indicates that the interaction between the oxygen atom and H-graphene is exothermic.

Based on our results, the most stable structures are 8 and 9, the difference between the lowest and highest energy is $-0.017 \mathrm{Ha}(-0.475 \mathrm{eV})$ and structures 12,10 and 5 are less stable than other structures but more reactive.

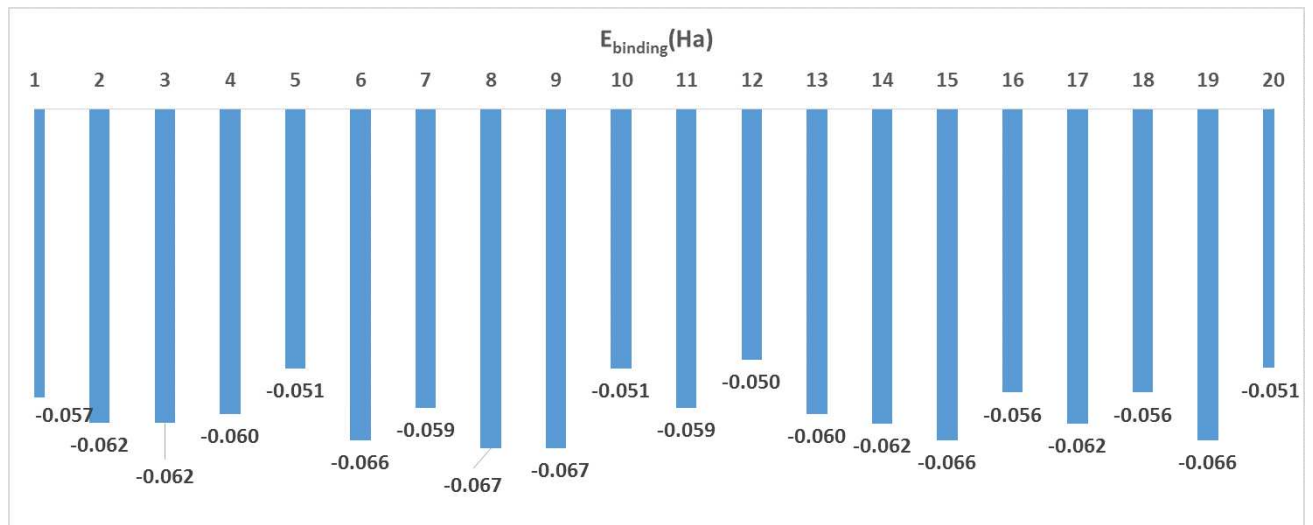

Fig. 3. Interaction energy between oxygen and H-graphene for the formation of H-graphene epoxy.

\section{OPTICAL PROPERTIES}

Quantum-mechanical computations have been performed for the electron absorption spectra of H-graphene and H-graphene epoxy structures in order to determine electron transitions in these structures. Figure S4 shows the oscillator power values relative to wavelengths by the time-dependent density-functional theory (TD$\mathrm{DFT}$ ). The values of the oscillator power of the wavelengths of the transmissions from HOMO $(\mathrm{H})$ to LUMO (L) and the wavelengths of the transmissions that have the most oscillator power values are shown in Table 3.

\begin{tabular}{llll|llll}
\hline Models & Transition & $\lambda_{(\mathrm{nm})}$ & $\begin{array}{l}\text { Oscillator } \\
\text { strength }\end{array}$ & Models & Transition & $\lambda_{(\mathrm{nm})}$ & $\begin{array}{l}\text { Oscillator } \\
\text { strength }\end{array}$ \\
\hline $\begin{array}{l}\mathrm{H}- \\
\text { graphene }\end{array}$ & $\mathrm{H} \rightarrow \mathrm{L}$ & 1044 & 0.0000 & 11 & $\mathrm{H} \rightarrow \mathrm{L}$ & 1390 & 0.1403 \\
1 & $\mathrm{H} \rightarrow \mathrm{L}+3$ & 518 & 0.8608 & & $\mathrm{H}-3 \rightarrow \mathrm{L}$ & 562 & 0.2292 \\
& $\mathrm{H} \rightarrow \mathrm{L}$ & 1233 & 0.0045 & 12 & $\mathrm{H} \rightarrow \mathrm{L}$ & 1285 & 0.0012 \\
2 & $\mathrm{H} \rightarrow \mathrm{L}+3$ & 585 & 0.5873 & & $\mathrm{H} \rightarrow \mathrm{L}+3$ & 553 & 0.3861 \\
& $\mathrm{H} \rightarrow \mathrm{L}$ & 1064 & 0.0016 & 13 & $\mathrm{H} \rightarrow \mathrm{L}$ & 1247 & 0.0051 \\
3 & $\mathrm{H}-3 \rightarrow \mathrm{L}+1$ & 459 & 0.4141 & & $\mathrm{H}-1 \rightarrow \mathrm{L}+2$ & 557 & 0.4233 \\
& $\mathrm{H} \rightarrow \mathrm{L}$ & 1063 & 0.0015 & 14 & $\mathrm{H} \rightarrow \mathrm{L}$ & 1071 & 0.0424 \\
4 & $\mathrm{H}-3 \rightarrow \mathrm{L}+1$ & 459 & 0.4134 & & $\mathrm{H} \rightarrow \mathrm{L}+3$ & 532 & 0.7270 \\
& $\mathrm{H} \rightarrow \mathrm{L}$ & 1247 & 0.0049 & 15 & $\mathrm{H} \rightarrow \mathrm{L}$ & 967 & 0.0145 \\
5 & $\mathrm{H}-3 \rightarrow \mathrm{L}+2$ & 557 & 0.4234 & & $\mathrm{H}-3 \rightarrow \mathrm{L}$ & 522 & 0.4556 \\
& $\mathrm{H} \rightarrow \mathrm{L}$ & 1224 & 0.1750 & 16 & $\mathrm{H} \rightarrow \mathrm{L}$ & 1326 & 0.0013 \\
6 & $\mathrm{H}-3 \rightarrow \mathrm{L}$ & 560 & 0.2164 & & $\mathrm{H} \rightarrow \mathrm{L}+3$ & 560 & 0.3621 \\
& $\mathrm{H} \rightarrow \mathrm{L}$ & 967 & 0.0141 & 17 & $\mathrm{H} \rightarrow \mathrm{L}$ & 948 & 0.3529 \\
7 & $\mathrm{H}-3 \rightarrow \mathrm{L}$ & 522 & 0.4582 & & $\mathrm{H}-4 \rightarrow \mathrm{L}$ & 466 & 0.4034 \\
& $\mathrm{H} \rightarrow \mathrm{L}$ & 1383 & 0.1450 & 18 & $\mathrm{H} \rightarrow \mathrm{L}$ & 1323 & 0.0013 \\
8 & $\mathrm{H}-3 \rightarrow \mathrm{L}$ & 562 & 0.2227 & & $\mathrm{H} \rightarrow \mathrm{L}+3$ & 559 & 0.3608 \\
& $\mathrm{H} \rightarrow \mathrm{L}$ & 969 & 0.0076 & 19 & $\mathrm{H} \rightarrow \mathrm{L}$ & 967 & 0.0140 \\
9 & $\mathrm{H}-3 \rightarrow \mathrm{L}$ & 523 & 0.5314 & & $\mathrm{H}-3 \rightarrow \mathrm{L}$ & 522 & 0.4661 \\
& $\mathrm{H} \rightarrow \mathrm{L}$ & 868 & 0.0573 & 20 & $\mathrm{H} \rightarrow \mathrm{L}$ & 1220 & 0.1791 \\
10 & $\mathrm{H} \rightarrow \mathrm{L}+4$ & 494 & 0.6596 & & $\mathrm{H}-3 \rightarrow \mathrm{L}$ & 560 & 0.2185 \\
& $\mathrm{H} \rightarrow \mathrm{L}$ & 1512 & 0.0630 & & & & \\
\hline
\end{tabular}

Table 3. The oscillator strength and wavelength of electronic transitions of HL and the wavelength of electronic transitions with maximal oscillator strength by TD-DFT.

Electron transmissions from HOMO to LUMO have the highest wavelength and the least amount of oscillator power in all structures. Comparison of the highest wavelengths of H-graphene epoxy structures with H-graphene shows that some H-graphene epoxy structures have a higher wavelength of the electron transfer from $\mathrm{H}$ to $\mathrm{L}$ and some have a lower wavelength than H-graphene (Table 3 ). The highest wavelength of electrons when transmitted from $\mathrm{H} \rightarrow \mathrm{L}$ comes from structure 10 (1512 nm), which is consistent with the results of the energy gap and global softness. In H-graphene, the lowest wavelength, $451 \mathrm{~nm}(2.75 \mathrm{eV})$, is attributed to the transmission of $\mathrm{H}$ - 
2 to $\mathrm{L}+1$ and the wavelength, $518 \mathrm{~nm}$, has the highest oscillator power $(\mathrm{H} \rightarrow \rightarrow \mathrm{L}+3)$. In structure 10 , the highest amount of oscillator power is attributed to the $\mathrm{H}-2 \rightarrow$ L electron transfer with a wavelength of $619 \mathrm{~nm}$ and the lowest wavelength with the energy of $42.2 \mathrm{eV}$ is attributed to the H-5 electron transfer to L.

\section{CONCLUSIONS}

The presence of functional groups led to changes in the properties and applications of $\mathrm{H}$-graphene, and $\mathrm{H}$ graphene epoxy is one of the remarkable structures of H-graphene. A review 20 places for epoxy on the surface of H-graphene shows that the presence of oxygen between two carbon atoms causes the bond lengths of these two carbon atoms to increase with respect to the length of the bonding of the same carbon in graphene. In all structures, the bond order decreases with increasing the length of the bond. These results are consistent with the results of the electrostatic potential. Comparison of the energy gap of H-graphene epoxy structures with $\mathrm{H}$ graphene shows that some of these structures have more energy and some have less than graphene. Structure 10 has the lowest energy gap and the highest global softness and therefore more reactivity. The energy gap matches the density of states. The calculations show that the number of electron occupation modes in the Fermi level range, after the absorption of oxygen on the surface of H-graphene has changed, which shows the effect of oxygen on the H-graphene surface. It was observed upon examination of density of states with spin up and down that $\mathrm{H}$-graphene is antiferromagnetic and the oxygen ab- sorption does not alter this property. The results of the Fukui functions calculations are consistent with the results of boundary orbitals. Oxygen in structure 10 had the highest amount of Fukui indices. The interaction energy shows that structures 12,10 and 5 are less responsive than other structures, and their stability is lower. Optical measurements show that, in all structures, the electron transfer from HOMO to LUMO, which is related to the energy gap, has the highest wavelength and the least amount of oscillator power. The highest wavelength in the transmission of $\mathrm{H} \rightarrow \mathrm{L}$ is attributed to the structure of $10(1512 \mathrm{~nm})$, which is consistent with the results of energy gap and global softness.

\section{SUPPLEMENTARY INFORMATION (SI)}

All additional information on Density of states and frontier orbitals (Fig. S1), The DOS of spin up and spin down electrons (Fig. S2), Electrostatic potential energy (Fig. S3), The oscillator strength values in terms of wavelength (Fig. S4) for H-graphene and H-graphene epoxies are provided in the supporting information available at https://doi.org/10.30970/jps.23.1301sm.

\section{ACKNOWLEDGEMENTS}

This work was supported by 1861 project from Semiconductors group, Institute of Science and High Technology and Environmental Sciences, Graduate University of Advanced Technology, Kerman, Iran.
[1] C. Yu, W. Jie, L. Zhong-Ming, Chinese. J. Anal. Chem, 40, 1772 (2012); https://doi.org/10.1016/ S1872-2040 (11) 60583-5.

[2] L. Grande, V. T. Chundi, D. Wei, C. Bower, P. Andrew, T. Ryhanen, Particuology 10, 1 (2012); https: //doi.org/10.1016/j.partic.2011.12.001.

[3] T. Szabo et al., Chem. Mater 18, 2740 (2006); https: //doi.org/10.1021/cm060258+.

[4] W. Cai et al., Science 321, 1815 (2008); https://doi. org/10.1126/science.1162369.

[5] D. W. Boukhvalov, M. I. Katsnelson, J. Am. Chem. Soc. 130, 10697 (2008); https://doi.org/10.1021/ ja8021686.

[6] A. Lerf, H. He, M. Forster, J. Klinowski, J. Phys. Chem. B 102, 4477 (1998); https://doi.org/10.1021/ jp9731821.

[7] A. J. Page et al., Phys. Chem. Chem. Phys, 15, 3725 (2013); https://doi.org/10.1039/C3CP00094J.

[8] X. Zhu, H. Su, H., ACS Nano 8, 1284 (2014); https: //doi.org/10.1021/nn404563k.

[9] D. W. Boukhvalov, D. R. Dreyer, C. W. Bielawski, Y. W. Son, Chem. Cat. Chem, 4, 4 (11), 1844 (2014); https://doi.org/10.1002/cctc. 201200210.

[10] H. Kim, A. A. Abdala, C. W. Macosko, Macromolecules
43, 6515 (2010); https://doi.org/10.1021/ma100572e.

[11] D. Galpaya et al., Graphene 1, 30 (2012); https://doi. org/10.4236/graphene.2012.12005.

[12] D. Cai, M. Song, J. Mater. Chem. 20, 7906 (2010); https://doi.org/10.1039/COJM00530D.

[13] J. T. Choi et al., Smart. Mater. Struct. 21, 075017 (2010); https://doi.org/10.1088/0964-1726/ $21 / 7 / 075017$.

[14] W.-H. Zhao et al., Comput. Theor. Chem, 1068, 1 (2015); https://doi.org/10.1016/j.comptc.2015.06. 009.

[15] H. T. Larijani, M. D. Ganji, M. Jahanshahi, Roy. Soc. Chem. Adv. 5, 92843 (2015); https://doi.org/10. 1039/C5RA16683G.

[16] T. Tista Basak, H. Chakraborty, A. Shukla, Phys. Rev. B 92, 92, 205404 (2015); https://doi.org/10.1103/ PhysRevB.92.205404.

[17] D. P. Karki, N. P. Adhikari, preprint arXiv:1404.6446 (2014).

[18] B. Delley, J. Chem. Phys. 113, 7756 (2000). https: //doi.org/10.1063/1.1316015.

[19] A. D. Becke, J. Chem. Phys. 98, 1372 (1993); https: //doi.org/10.1063/1.464304.

[20] B. Delley, J. Phys.Chem. 100, 6107 (1996); https:// 
doi.org/10.1021/jp952713n.

[21] C. Lee, W. Yang, R. G. Parr, Phys. Rev. B 37, 785 (1998); https://doi.org/10.1103/PhysRevB.37.785.

[22] B. Delley, J. Chem. Phys. 92, 508 (1990); https://doi. org/10.1063/1.458452.

[23] W. Yang, W.; R. G. Parr, Proc. Natl. Acad. Sci, 82, 6723
(1985); https://doi.org/10.1073/pnas.82.20.6723.

[24] C. Morell, A. Grand, J. Phys. Chem. A 109, 205 (2005); https://doi.org/10.1021/jp046577a.

[25] I. Mayer, Chem. Phys. Lett. 97, 270 (1983); https: //doi.org/10.1016/0009-2614(83)80005-0.

\title{
ВПЛИВ ПОЛОЖЕННЯ ЕПОКСИДНОЇ ГРУПИ НА ВЛАСТИВОСТІ КЛАСТЕРА Н-ГРАФЕНУ: РОЗРАХУНКИ МЕТОДОМ ФУНКЦІОНАЛА ГУСТИНИ
}

\author{
Фахіме Шоджае \\ Вища вища школа передових технологій, Керман, Іран \\ e-mail:f.shojaie@kgut.ac.ir
}

Хімічну функціоналізацію кластера Н-графену епоксидною групою вважають ефективним способом налаштування електронної структури Н-графену і відкриття його забороненої зони. Важливо розуміти атомну структуру оксиду Н-графену, щоб використовувати його фундаментальні властивості та досліджувати потенційні застосування. Тому потрібно знати розташування кисневмісних функціональних груп в оксиді Н-графену. У цій роботі проведено обчислення з використанням дескрипторів реактивності на основі методу функціонала густини для визначення сприятливих ділянок епоксидних груп на поверхні Н-графену. Порівняно структурні, електронні та оптичні властивості епоксидних груп у різних положеннях на поверхні Н-графену. Всі розрахунки виконано з використанням коду $\mathrm{DMol}^{3}$ у Material Studio. Оптичні властивості епоксидних груп показують, що електронні передачі від HOMO до LUMO, які пов'язані з енергетичною щілиною, мають найбільшу довжину хвилі й найменшу силу осцилятора в усіх структурах. Найбільша довжина хвилі, що виникає в переході $\mathrm{H} \rightarrow \mathrm{L}(1512 \mathrm{Hм})$, пов'язана зі структурою 10. Це узгоджується з результатами щодо енергетичної щілини і ґлобальної м'якості. Енергія взаємодії від'ємна у всіх структурах. Цей факт указує на те, що взаємодія між атомом кисню і Н-графеном, яка приводить до утворення епоксиду Н-графену, є екзотермічною. Заповнення електронних станів на енерґетичних рівнях між HOMO і LUMO змінюється для Н-графену, який абсорбував кисень, що засвідчує вплив кисню на поверхню Н-графену. 